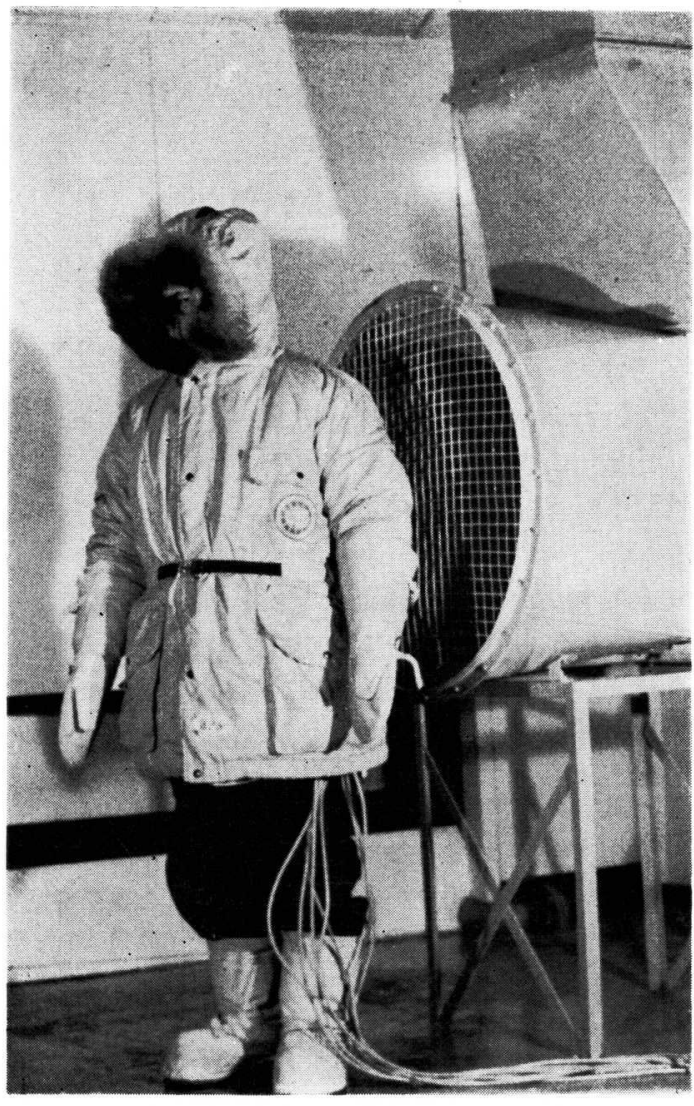

「人間工学」といら言葉は, 最近では繊維業界におい てしばしば問題にされ，その意味するものは主題からら外 れていないものの，その見方は様々である。緎維業界に おける人間工学は, 工程面では man-machine system の 最適組合せであり製品面では如何にして美しくかつ着心 地よい衣服を作るかが最大の問題となっている。前者は 工程における人間の疲労度を最少に押え, 生産をより能 率的に安全に行なわしめるために必要とされこの方面で の研究は設計, 計装および品質管理に携わっている人々 の苦心に依っている。一方後者は, 被服構成の要素とし $\tau$, 美感, 機械的性質, 衛生的性質, 機能的性質等に分 けることが出来, 人間工学を特に必要とするのは機能的 性質であろう。現在機能量の把握は完全でなく, 笳電 図, G S R, 心電図等医療関係の測定器具はあるが, これ 等の測定から得られた Data の意味するものが，人間の 真の感じ方を示しているかどらかは甚だ不確実である。 そのため現段階での判定では実際の人間の感覚量に頼る ところが大きく，生産面では所謂 Designer と称する人

\section{Some problems in suits design}

by M. Okumura. TEIJIN KK

\section{纖維業界からみた 人間工学}

帝人KK繊維加工研究所 奥 村 真 澄
達によって判定が行なわれている場合が多い。

消費者は衣服を購入するとき，その価格に対して，緎 維物性 (衛生的機能孔含导), 色, 柄, 形, 機能性等を問 題にする。そこで本稿ではきしくかつ機能性のある既製 服を作るために，人間工学的要素を如何なる方法で取り 入れることが出来るか，またそれにおける問題点につい て述べる。

\section{1. 人体寸法の把握}

衣服は身に緾らものであるから，身体計測は基本的な 問題である。現在既製服作成のために必要な日本人の体 格体型の分布状態は正確に把握されておらず, 現在まで にある身体計測デー夕は計測者により, 採寸個所, 方法 が異なるためこれ等の Data を集計しても正確な分布状 態を把握することは不可能である。これを可能にするに は計測方法を明確に統一にし, 一定の計测教育を受けた 計測者が実際の計測に当り, 被計測者の選定は人類学的 
見地と衣服的見地から層別を行ない，その層 内で任意抽出して, 日本人の縮図を作る必要 がある。また被計测者数は Pre-sampling を 行ならことによって，その分散状態と衣服精 度，並びに計測精度から決定される。

次に計測した Data は性別, 年令別, 未既 婚別, 地域別等に層別を行ない, 各計測項目の 平均值, 標準偏差を求め, 層間の差の検定を 行ない，衣服的にみて差のないものは統合し て，大きな group に区分する。例えば年令 の場合18２4才に緾める。そしてこの group 内で, 各計測項目の平均值, 標準偏差を求め 寸法区分の基礎的数字とする。

\section{2. 寸法区分}

普通一般の機械は視覚や動作の適応範囲が 非常に広 く, 一種類のもので人間の 80 〜 90\%を cover している のに比へ，衣服の場合には通常一種類の衣服での人間の cover 率は極く僅かである。つまり衣服の許容差（感覚 幅）は身体寸法によって細かく制限を受ける。そこで衣 服を作るために人体寸法を如何なる方法で区分するかが 問題となる。

第 1 に考えられる方法は各計測項目の多次元散布図を 作成し，この各項目を何個かに等分し，全項目の組み合 わせを作る。つまり $\mathrm{B}-\mathrm{W}-\mathrm{H}$ 一袖丈一肩巾……各項 目の中心值を中心として等分し，その組み合わせを作る 方法である。しかしこの方法によると膨大なサイズ区分 例えば計測項目を30項目，各々を5 等分した場合その組 み合わせは $5^{30}=9 \times 10^{20}$ となる。1 Design で業者は到 底これだけの Size 数は作れないし, 常識からみてもこ れだけの Size 数は必要でない。

第 2 の方法は各計測項目間の相関俰数を求めて, 代表 項目で規定する方法である。この相関係数を 取る意義は, 計測項目相互間の相関係数を求 め, 相関の高いものは，ある代表項目を取る ことによって, 回帰式から各項目が推定する ことが出来ることにある。このよらにすれば 第1の方法の組み合わせを大幅に減らすこと が出来る。しかし全ての項目に渡って相関が 高い項目はなく,丈方向の項目内, 回り方向の 項目内, 幅方向の項目内では相関が高いが, 丈方向と回り方向と幅方向に涂り相関がな いし, 回り方向でも上半身と下半身とでは相 関が少ないので, この方法も最適の方法とは いえない。

第 3 は重相関係数を求め多重回帰式で推定 する方法である。人間の各部分は,丈方向, 回

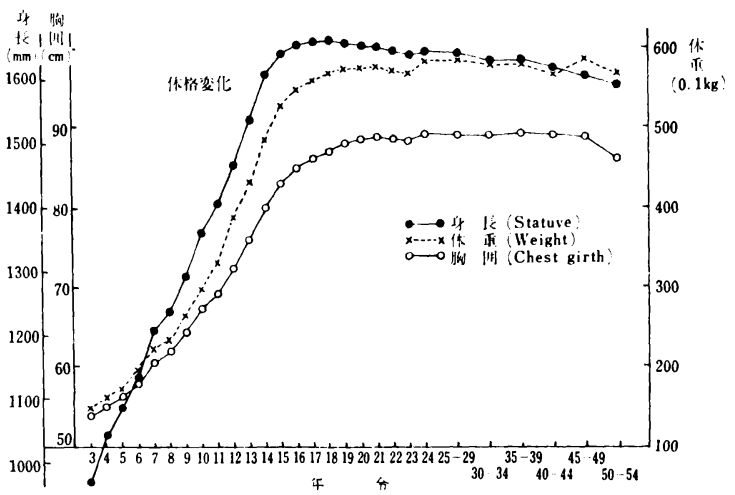

第 1 図 男子の体格変化

り方向, 幅方向と単独に相関をもっているのではなく,お 互いにある程度の関係をもっているし項目によっては丈 と回りとに同じ割合で相関があるのもある。また単相関 係数は小さくても重相関を取ることによって相関係数が 高くなる項目もある。これ等のことから多重回㷌式で他 の詳細な項目を推定すれば，精度はさらに良くなる。こ の多重回帰式の独立变数は各項目に渡って相関が高く既 製服作成上重要な項目が必要とされ，これを重要規定項 目とする。次にこの重要規定項目の多次元散布図を書 き各々の値をパーセンタイル值, 標準偏差, 又は衣服の 感覚幅でもって区分幅とし, 回帰俰数や Grading のし やすさ, proportionの美しさ（両者とも現段階では定義 されていないが) 等を考虑して寸法分類を行なら。回帰 式に寸法分類された重要規定項目の値を代入して，他の 詳細な項目を推定する。

\section{3. 人体の体型把握}

今をでの原型及び製図の引き方を知っていれば，前述

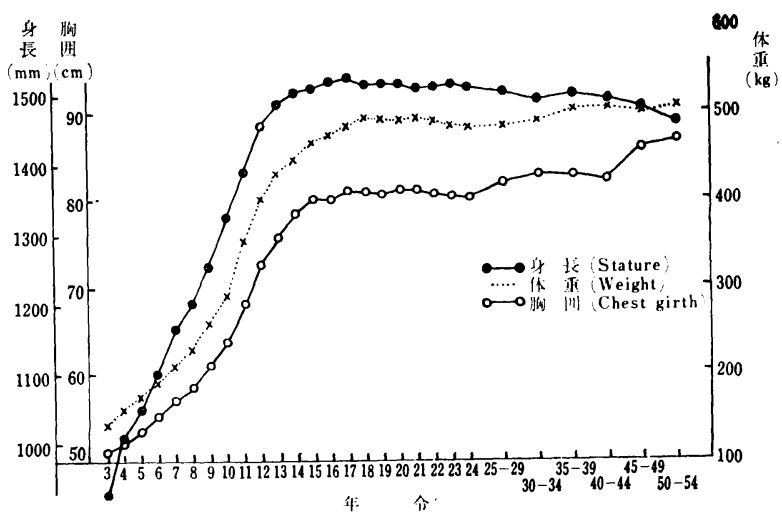

第 2 図女子の身長・体重・胸囲の体格変化 
の詳細な寸法で型紙は作成出来るが，衣服を作るとき， 何回も仮縫を行なっている現状は，個人的な好み以外に 原型や Grading の仕方に根本的な問題を含んでいると いえよう。また最近では立体裁断が盛んに使われている が，体型分類された具体的な人体がはっきり決定されて いない現段階では，既製服の立体裁断は不可能である。

今までの人体計測は単に丈, 高, 囲, 幅, 径の寸法し か計測していないが，体型把握のためにはこれだけでは 不十分であって立体的な計測つまり一軸を中心とした 3 次元の寸法を同時に計測する必要がある。現在カメラを 使ったり，紙，石育等で人間の体型を求める研究が一部 行なわれているが，計測数がわずかであり，具体的な体 型分類には到っていない。W. H. Sheldon 等が相当詳 しく体型分類を行なっているが，その判定は高等技術を 要し, 一般には困難である。

そこで体型分類の簡便法として，体型と人体寸法とは 厳密には関係がないかも知れないが，衣服作成に必要な 体型と人体寸法とは関係していると考兄，前述の寸法区 分表から各々の枠の中に入る代表的人物を抽出し，その 人を立体計測する。その值が一つの枠の中に入る全ての 人の代表体型とする。勿論この計測を行ならときの人間 の姿勢は直立不動でなく，日常生活と余り変わらない自 然に Relax した状態で計測する必要がある。

\section{4. 人体の運動量の把握}

初期に於いては, 人間の関節部が屈伸運動によってど れ程変形するかを観察し, 現在用いられているジャージ やストレッチ織物の必要伸縮度を求め, 製品設計の目安 としていた。次に皮膚に碁盤状の線や円を描き，各種の 運動をしたときの変形量と方向を求めた研究があった。 この実験から求めた伸びは皮膚本来の伸びと各部に蓄え られた毁の伸びとが合成されたものであり，foundation garments, 肌着の分野を除いて直接衣服構成に応用する ことは出来ない。何故なら織物の伸びは瀻維本来の伸び と織物の組織構造のずれからなり皮膚の伸びより織物の 伸度ははるかに少なく（ジャージ，ストレッチは除く）, しかも回復率は前者は完全にもとの位置に回復するに比 へ，後者は必要以上に伸ばされたとき，後に歪が残り，时 抜け，解の原因となるからである。ゆとりのない場合には 皮膚に対する衣服の圧迫は非常に強く，機能性の全々な い衣服となる。そこで衣服がいつも機能性があり，毁に ならずしかも美しさを保つためには最適のゆとり量が必 要となる。また人間の皮膚の運動量ではなしに, 人間が 動作をしたとき，ゆとり量の変化によって皮膚と衣服が どれ位変形し，その両者のずれがどの程度起り，その変 形によって衣服が皮膚をどの程度圧迫するかを観察する ことが重要である。
次に必要なことは人間の運動は関節を中心にして行な われるが，この運動の方向と量及び衣服に与える影響量 を観測しなければならないこでとある。何故なら，平面 の織物を立体の人体に着せ, 機能性や美しいシルェット を出すために織物にダーツ,タック等を入れるが,これ等 の方向や量は体型把握のときの必要とは別に，骨格の運 動からも求めなければならない。もら一つの問題は衣服 の着心地の判定である。人間が運動したとき人体の各部 に変形と压迫が生じるが，たとえその量が人体各部で一 律であるにしろ，人間に与える着用感は異なるはずであ る。着用感の判定は今のところ GSR, 心電図, 脳波等 医療関係の測定器が考えられるが，満足し得る測定器は なく，もっぱら人間の言葉を媒介にして判定しているの が現状である。

よって衣服による皮唐の变形（物理量）－着用感（感 覚量） $\rightarrow$ 物理量を観測し得る計器の開発が急務となる。

\section{5. 既製服のための Dummy の作成}

重要規定項目で寸法分類された各 group から代表的 な人間を再度抽出し，各人を立体計測を行ならことによ って体型分類された人体 Body が作成される。この人体 Body は人体の体型そのままであるからこのBody を土 台にして pattren 作りを行なっても必ずしも機能性のあ る美しい衣服とはなり得ない。既製服のための Dummy が必要とされ，その作成にあたっては，人体 Bodyを proportionの美しさ, grading のしやすさ, 基本的な運 動量等で修正しなければならない。例えば18才〜24才未 婚女性の軀幹部の平均寸法は別表のようになるが，その

18才 24才 未婚女子人体寸法

\begin{tabular}{lr|llr}
\hline 体重 & $49.2 \mathrm{~kg}$ & 身 & 長 & $154.2 \mathrm{~cm}$ \\
首付根囲 & $35.3 \mathrm{~kg}$ & 総 & 丈 & $132.7 \mathrm{~cm}$ \\
chest girth & $80.0 \mathrm{~cm}$ & 袖 & 丈 & $50.0 \mathrm{~cm}$ \\
bust girth & $81.0 \mathrm{~cm}$ & 背 & 丈 & $38.3 \mathrm{~cm}$ \\
under bust girth & $69.6 \mathrm{~cm}$ & 腰 & 丈 & $19.0 \mathrm{~cm}$ \\
waist & $60.0 \mathrm{~cm}$ & 脇 & 丈 & $97.0 \mathrm{~cm}$ \\
hip & $89.3 \mathrm{~cm}$ & 前 胴 高 & $94.2 \mathrm{~cm}$ \\
胸 幅 & $31.1 \mathrm{~cm}$ & 膝 & 高 & $38.6 \mathrm{~cm}$ \\
背 幅 & $32.9 \mathrm{~cm}$ & 乳下り丈 & $32.1 \mathrm{~cm}$ \\
乳頭間隔 & $18.1 \mathrm{~cm}$ & & & \\
\hline
\end{tabular}

值を従来の製図方法にそのま〉適応しても又この寸法の 人体Body から立体裁断を行なって衣服を作っても胸の 平坦な全体的にバランスの取れない衣服となるであろ ら。つまり衣服の proportion の美しさを出すためには 人体 Body を foundation garments で矯正ざれた寸法 形にしなければならない。それと共に衣服として人体の 
形状がそれ程必要とされない個所は単純化す ればよい。

このよらにして作られた Dummy は，衣 服を作るための基礎となり，この Dummy で立体裁断を行なえば一つの体型の人に fit した衣服の作成が可能となる。

\section{6. 被服構成}

Dummy が作られたといっても Cuttingの 仕方一つで機能性の良し苾しは左右される。 家政学会, 衣服学会, 消費科学会では Cutting に関する研究が非常に多く発表されている。 特に個人の原型に関する研究は数多く行なわ れている。しかしその判定は視覚的な要素が 多分に含まれており，着心地を物理量に還元 した判定はほとんどない。又いろいろな体型に分類した 後, その各々についての原型作成はほとんど行なわれて おらず，一つの原型で全ての人間をし得ると考えている 場合が多い。

既製服の場合，Dummy が完成したならば，これに合 わせて立体裁断すれば, いわゆる原型の作成は不要であ ろう。くりの形状, ダーツ, タックは機能性と大いに関 係しているので, 既製服の場合, 立体裁断をするとき, これ等と機能性との関係を把握しておく必要がある。

Designer は，自分のイメージを衣服を表現するとき これ等を基本として cutting を行なえば良い。

つぎにたとえその原型が機能的に最適のわのであって も既製服の場合, 量的な生産が可能な, つまり Cuting しやすく, 縫製工程が簡単であることも必要条件に挙げ られる。

\section{7. 特 殊 服}

人間工学的見地から最も深い研究が要求される衣服に 作業服, 制服としての事務服, 防寒防暑服, 航空服等が ある。これらは限定された領域で使われる衣服であり, シルェットの美しさよりも機能性, その場所での色彩的 な事などが問題となる。

作業服はある決められた場所で全身的な又は部分的な 動作を行ならための衣服であり疲労性を防ぎ大きな運動 に対する機能性に富むるのが要求される。又その色彩は 作業場での安全性を考虑したものであらねばならない。

事務服での仕事は坐った状態で, 腕を机上で動かすの が主な動作であるから，事務服のアームホールの形状， 袖山の形状は, 腕の水平方向の運動に対して十分その機 能を発揮しなければならないし，上半身の屈伸運動に対 して長時間衣服による疲労が生じないものでなければな

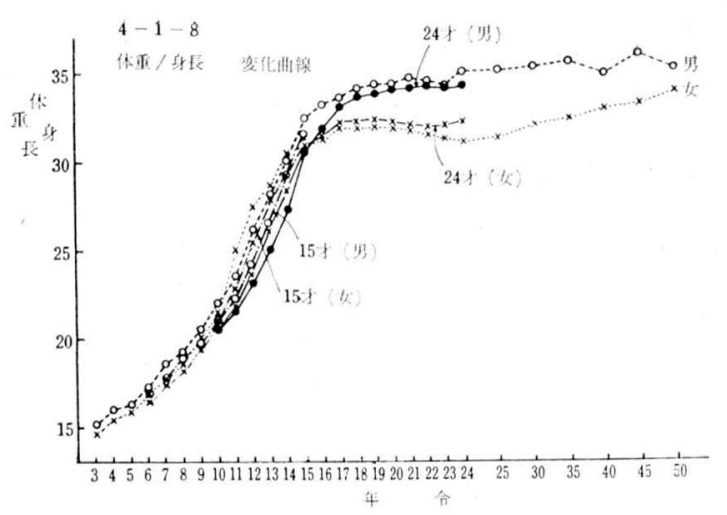

第 3 図 15 才と 14 才の男女の身長/体重生長曲線

らない。又事務所は多勢の人が一ヶ所で仕事をするので その場所での雾囲気を乱さず視喾的な疲労を少なくし， 能率的に仕事を行ならために事務服は室の色や備品の色 と調和した色彩とデザインを選ばれなければならない。

防寒, 防暑服, 航空服 (与圧服) は日常の世界之非常 に異なった状態のところで使用され，直接生命に影響を 及ぼす衣服であるからその設計は十分慎重に行なら必要 がある。例党ば南極探検で使用される防寒服はー $30^{\circ} \sim-$ $40^{\circ} \mathrm{C}$ の極寒の状態で被服内温度を普通の状態に保たな ければならないので，その被服構成は保温性を有する材 質を用いると共に，歩行運動に対して疲労感を伴わない よう軽く，機能性のある衣服を作る必要がある。

衣服といらものは人間の一部であり, 今後人間とのも のを一層深く解明することによって, より合理的な着心 地の良い衣服を作ることが出来るであるらと考える。

(カット写真は南極観測隊用の防寒服研究風景——温室 $-40^{\circ} \mathrm{C}$ 風速 $25^{\mathrm{m}} / \mathrm{sec}$ )

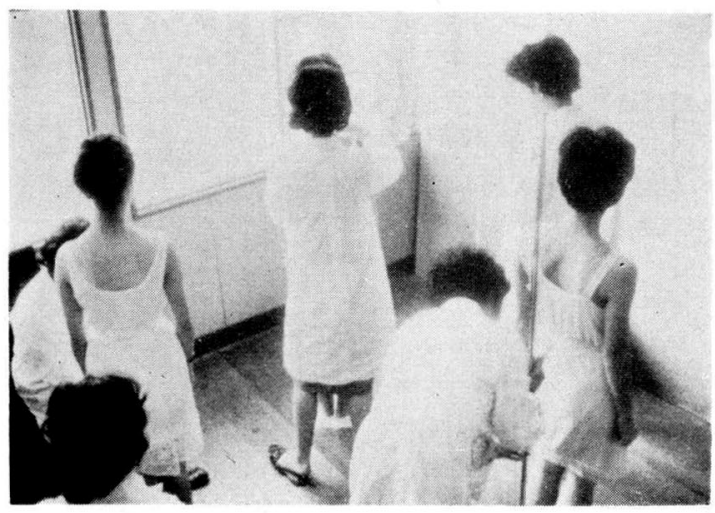

第 4 図女子の計測状景 
Mechanism of brain : by Toshihiko Tokizane

The characteristics of the brain mechanism were reviewed with special reference to three integrative systems of the brain : the neocortical, limbic and brain stem-spinal systems. The limbic system integrates the instinctive and emotional behaviour making use of somatic informations of primitive nature and those changes of internal environments which are received at hypothalamus, while the brainstemspinal system corresponds to reflective and regulative actions mobilized by pain, muscular tension, sense of equilibrium and changes in internal environments. The adaptive and creative behaviour is integrated at the cerebral neocortex taking advantage of somatic input from external environment. Its output mechanism belongs to the frontal lobe in terms of thinking, reasoning and decision: making in contrast with input mechanism in those cortical areas located posterior to the central and lateral fissures which are related to percepting, understanding and memorizing. The consciousness and attention are the complex neocortical functions activated by brainstem reticular system and hypothalamic regulative system.

\section{Ergonomic studies on the improvement}

\section{of the universal laithe : by kenzo Aihara}

Ergonomic studies were performed to design an mproved type of the universal laithe. Layout of controls was especially considered so that they may be concentrated within the operator's reach according to their functional importance and to the sequence of operation. The diminution of the number of controls was also intended. The required force for the tail-stoch controls was reduced. In order to evaluate the new model, operation time and processing time were measured and motion study by means of memomotion technique and cyclegraph was performed. The results showed conspicuous reduction of operation and processing time, frequency of hand or foot motions and body bending as compared with laithe of older types.

\section{Test and evaluation of snow-car for anta- rctic research expedition: by Naoshi Kajii.}

The snow-weasel weighing $8.5 \mathrm{t}$ with a Diesel engine which was designed to accomodate 3 persons in $-2^{\circ} \mathrm{c}$ to $-40^{\circ} \mathrm{c}$ conditions was studied from ergonomic viewpoints. The check-list method was applied to check the microclimate, noise and vibration, illumination, clothes, water supply and sewage, seats, displays and controls. Some problems were revealed by this method as to temperature regulation, defroster, noise while driving, vibration, absence of lavatory or water supply, bed space and kitchen table. The improvement of window space, seat design, layout of controls, countermeasures for emergency and temperature regulation was recommended.

Improvement of the ticket issuing at the open counter of Tokyo Station : by Kinji Aizawa

Open counter system of the tickets issuing for the new high-speed rail-way service, the new Tōkaido line, was studied to promote the efficient and comfortable issuing. The appropriate seat height, seat back sufficient space for feet and legs were arranged so as to emable the comfortable posture. The control panel to have access to the electronic computer was set at the left, the ticket printer at the right of the clerk within adequate reach and with proper height. The printer areas may be used for handing over of the ticket to another clerk in case of two-men issuing. The tecket-box for subsidiary use was set accordingly at the back of the clerk. The new design was actually adopted at the Tokyo station and gained popular favour. The hourly issue speed reached over 60 per clerk.

\section{Some problems in suits design : by Masumi Okumura}

Methodological problems to meet ergonomic demands for suits are discussed as to size dimensions. The proper classification of necessary dimensional data may be offered by means of multiple regression analysis of the measurements. The understanding of body types and finding of adequate allowances for body motion require the development of new techniques of analysis. The manufacture of the dummy for ready-made suits may provide us the possibility for thier 3-dimensional cutting and thus for the manufacture of suits fit for every body type.

Methodology of ergonomics - work study, It' application to ergonomics - by Kazuo Tsubouchi

Explanatory remarks on study methods for human work motion are described. In this article the therblig method and the use of a simo chart are introduced. 